\title{
Unit of Spread Rate of Substance by Volume
}

National Cancer Institute

\section{Source}

National Cancer Institute. Unit of Spread Rate of Substance by Volume. NCI Thesaurus.

Code C92570.

An indication of the type of unit of measure being used to express a spread rate of a substance by volume. 